\title{
DETERMINING AGRICULTURE PRODUCTION EFFICIENCY BASED ON THE NEW ASSESSMENT TOOLS
}

\author{
Dmitri PARMACLI', Habilitation in Economics, Professor, \\ State Comrat University, Republic of Moldova \\ Alexandru STRATAN', Habilitation in Economics, Professor, \\ National Institute for Economic Research, Republic of Moldova
}

\author{
DOI: https://doi.org/10.36004/nier.es.2019.2-01 \\ JEL Classification: M41, I10, L31 \\ UDC: 631.158:005.52
}

\section{ABSTRACT}

Profitability indicators describe the result of the management process more comprehensively than profit, characterize the effectiveness and efficiency of management, because their value shows the ratio of the effect with cash or input resources. They are used to evaluate the performance of the enterprise, as well as an instrument of investment policy and pricing. Most often, in practice, agricultural enterprises calculate indicators that characterize the profitability of production costs, investment projects and profitability of sales. It is very important to calculate the profitability levels of each type of sold products and give them an estimate, which allows identifying the most profitable ones. Methodological approaches are proposed in order to determine the four levels of profitability of the sold products, which are clearly presented in tables and graphs. It is important to grade the levels of profitability for each type of sold product, and therefore, it is becoming possible to assess their degree of effectiveness or level of profitability. The purpose of the article is to provide teachers from higher educational institutions, as well as agricultural specialists with modern tools for assessing the effectiveness of sold products, in particular through application of an unconventional method. The presented study allows specialists of agricultural enterprises to determine on the basis of two coefficients (return on fixed and specific variable costs) the moderate, rational, optimal and high profitability of sold grain, sunflower, grapes and other products and based on them to justify the amount of expected profit.

Keywords: profitability, profit, efficiency, profit margin, rate of return, fixed costs, price, variable costs per unit, cost.

Indicatorii de rentabilitate descriu rezultatul procesului managerial mai cuprinzător decât profitul, caracterizează eficiența și eficacitatea managementului, dat fiind faptul că valoarea acestora prezintă relația dintre efect și resursele de numerar sau cele utilizate. Aceștia sunt utilizați pentru a evalua activitățile întreprinderii, precum și în calitate de instrument al politicii investiționale și de stabilire a prețurilor. În cele mai dese cazuri, în practică, întreprinderile agricole calculează indicatori care caracterizează rentabilitatea costurilor de producție, a proiectelor de investiții și a rentabilității vânzărilor. Este foarte important de a calcula nivelurile de rentabilitate ale fiecărui tip de produse vândute și de a oferi o estimare a acestora, ceea ce va contribui la identificarea celor mai profitabile produse. Sunt propuse abordări metodologice pentru determinarea a patru niveluri de rentabilitate a produselor vândute, care sunt prezentate în mod clar în tabele și grafice. Este important de a evalua nivelurile de rentabilitate pentru fiecare tip de produs vândut, ceea ce permite evaluarea gradului lor de eficiență sau nivelul de rentabilitate. Scopul articolului este de a oferi cadrelor didactice din instituțiile de învățământ superior, precum și specialiștilor din domeniul agrar instrumente moderne pentru evaluarea eficienței produselor vândute, în special prin utilizarea unei metode neconvenționale. Studiul prezentat permite specialiștilor din întreprinderile agricole să determine în baza a doi coeficienți (rentabilitatea costurilor fixe și a costurilor variabile pe unitate) valoarea rentabilității moderate, raționale, optime și ridicate a cerealelor vândute, a florii-soarelui, strugurilor, precum și a altor produse și în baza acestora, să justifice valoarea profitului scontat.

Cuvinte-cheie: rentabilitate, profit, eficiență, marjă de profit, rata de rentabilitate, costuri fixe, preț, costuri variabile pe unitate, cost.

1 (C) Dmitri PARMACLI, $₫$ parmad741@mail.ru

2 @ Alexandru STRATAN, $₫$ alex_stratan@yahoo.com 
Показатели рентабельности описывают результат процесса управления более полно, чем прибыль, характеризуют результативность и эффективность хозяйствования, так как их величина показывает соотношение эффекта с наличными или использованными ресурсами. Их применяют для оценки деятельности предприятия и как инструмент инвестиционной политики и ценообразования. Чаще всего в практике сельскохозяйственных предприятий рассчитывают показатели, характеризующие рентабельность издержек производства, инвестиционных проектов и рентабельность продаж. Очень важно проводить расчеты уровней рентабельности каждого вида реализованной продукции и осуществлять их оценку, что позволяет выявить наиболее доходные из них. В данной статье предлагаются методические подходы по определению четырех уровней рентабельности реализованной продукции, наглядно представленные в таблицах и графиках. Важно проводить градацию уровней рентабельности по каждому виду реализованной продукции, в связи с чем представляется возможность оценивать степень их эффективности или уровень доходности. Цель статьи обеспечить преподавателей высших учебных заведений, а также специалистов сельского хозяйства современным инструментарием оценки эффективности реализованной продукции, в том числе с использованием нетрадиционного метода. Представленное исследование позволяет специалистам сельскохозяйственных предприятий, на базе двух коэффициентов (окупаемости постоянных и удельных переменных затрат) определять величину умеренной, рациональной, оптимальной и высокой рентабельности реализованного зерна, подсолнечника, винограда и другой продукции и на этой основе обосновать объем ожидаемой прибыли.

Ключевые слова: рентабельность, прибыль, эффективность, норма прибыли, норма прибыли, постоянные затраты, цена, переменные затраты на единицу, стоимость.

INTRODUCTION. Profitability indicators describe the outcome of the managerial process more comprehensively than profit because their values present the effect achieved as a function of the required cash or resource inputs. These indicators are applied to assess the farm's performance and as an investment policy and pricing tool. More often than not, agricultural enterprises calculate certain values that describe the profitability of production costs, investment projects and sales. It is very important to calculate and to assess the profitability of each type of sold products in order to identify the most profitable ones.

RESEARCH METHODOLOGY. This research was based on general scientific methods and certain specific approaches - and in particular an abstract-logical approach to substantiate the methodology applied to assess the efficiency of product sales; statistical and economic approach to analyse prevailing production and sales values for core crops in a given agricultural enterprise; graphic method to compare the actual efficiency of the cultivated crops with their graded profitability levels.

LITERATURE REVIEW. State-of-art agricultural science is looking for new ways to improve the efficiency of agricultural production. Of interest in this respect are the works by V.P. Pavlik $[1,2015]$ and by O.G. Szpikuljak and O.A. Materzynska [2, 2014] proposing a new approach for assessment of product efficiency and substantiating the efficiency growth drivers.

Economic literature considers the sustainability of land-use results from diverse perspectives. In particular, A. Rasskazova and R. Zhdanov introduce the concept of economic efficiency of sustainable land use in their publications [3, 2017]; S. Siptits considers the matters of combining the efficiency with sustainable operation of agro-food systems [4, 2017]; I. Romanenko and N. Evdokimova consider the sustainability and efficiency of such territorial distribution of crop production which would ensure a high degree of utilisation of the territory's bioclimatic potential [5, 2017]. Of importance is also the research performed by A.I. Altukhov [6, 2016]. The author of this latter research explores the current approaches to efficiency assessment of land use in agriculture.

The research performed by Moldovan authors and deserving special mention is the work by V. Doga and E. Timofti, who have developed and suggested in their studies their own versions for the economic engine to improve agricultural efficiency based on sustainable land use $[7,2006 ; 8$, 
2009]. Of importance is also the research by L. Todorici and T. Dudoglo, one of them considers the agricultural production sustainability problems $[9,2013]$ and the other assesses the sustainability of soil productivity in Moldova's regions [10, Dudoglo T., 2017].

The purpose of this article is to provide teachers from higher educational institutions, as well as agricultural specialists with modern tools for assessing the effectiveness of sold products, in particular through application of an unconventional method.

RESEARCH RESULTS. It is known that the performance of agricultural production is largely dependent on weather and climate, i.e. the factors which the current science is not able to forecast more or less reliably. No matter how thoroughly and correctly (in methodology terms) agricultural professionals plan their costs of materials and cash investments with due account of accepted production techniques, it is not possible to reliably forecast the expected crop yields and thus the gross output of the cultivated crops. Similar costs may result in high crop cultivation efficiency and sales profitability in good years and in losses in bad years. This instability is characteristic in particular of risky (marginal) farming zones and in particular of the southern zone of the Republic of Moldova [11, PARMACLI D., DUDOGLO T., 2016]. But then, how can one determine production costs, return on investments and other economic values reflecting management quality in the absence of any reasonably substantiated crop productivity data? That is where we apply marginal analysis as the most appropriate tool.

The research suggests that certain production and sales efficiency indicators finding application in agriculture (such as profit per hectare of the area under the crop and per $100 \mathrm{~kg}$ (metric centner) of harvested products; financial safety margin; and operating leverage) can be calculated with rather high reliability without recourse to the data on yield per hectare and gross output of the cultivated crops. It is known that fixed costs per hectare (FC) and variable costs per unit (AVC) are not affected by the yield per hectare. In other words, this specific nature of fixed costs and variable costs per unit will enable us to make the required efficiency calculations. It is important to estimate the expected selling price $(\mathrm{P})$ as objectively as possible as part of the planning process because neither does selling price depend on the output of any given enterprise since agricultural enterprises operate in an environment of free competition [12, PARMACLI D., 2016].

Knowing these three values, we can determine the profitability threshold $\left(\mathrm{q}_{\min }\right)$ for each crop according to the well-known formula:

where:

$$
\mathrm{q}_{\text {min }}=\frac{\mathrm{FC}}{\mathrm{p}-\mathrm{AVC}} \text { metric centners }(100 \mathrm{~kg}) \text { per hectare }
$$

$\mathrm{FC}=$ semi-fixed costs per hectare of the area under the crops, in MDL;

AVC = variable costs per unit of output, in MDL per metric centner $(100 \mathrm{~kg})$;

$\mathrm{P}=$ selling price of the product, in MDL per metric centner $(100 \mathrm{~kg})$.

Our research identified a certain interdependence between the economic efficiency values of the produced and sold products and the difference between the actual crop yield (q) and the breakeven yield (profitability threshold). To reflect this difference, we have introduced an indicator which we call the yield growth rate $(\mathrm{n})$ :

$$
\mathrm{n}=\frac{\mathrm{q}}{q_{\min }}
$$

Below are the formulas used to calculate the value of certain indicators reflecting the efficiency of marketable products in agriculture:

- profit per hectare:

$$
\mathrm{P}=\mathrm{FC}(\mathrm{n}-1) \text {, in MDL per hectare }
$$

- profit per unit - metric centner $(100 \mathrm{~kg})$ of products:

where:

$$
\mathrm{P}=\mathrm{md}\left(1-\frac{1}{\mathrm{n}}\right) \text {, in MDL per metric centner }(100 \mathrm{~kg})
$$

$\mathrm{md}=$ marginal income per product output unit $(\mathrm{md}=\mathrm{p}-\mathrm{AVC})$, in MDL per metric centner $(100 \mathrm{~kg})$ 
- financial safety margin (D):

- operating leverage (L):

$$
\mathrm{D}=1-\frac{1}{n}
$$

$$
\mathrm{L}=\frac{n}{n-1}
$$

Table 1 and Figure 1 below show the interdependence between profit and yield growth rate.

The interdependence between profit and yield growth rate

\begin{tabular}{|c|c|c|c|c|c|}
\hline $\begin{array}{c}\text { Yield growth } \\
\text { rate }\end{array}$ & $\begin{array}{c}\text { Profit per } \\
\text { hectare } \\
\text { growth rate }\end{array}$ & $\begin{array}{c}\text { Profit per } \\
\text { output unit } \\
\text { growth rate }\end{array}$ & $\begin{array}{c}\text { Yield growth } \\
\text { rate }\end{array}$ & $\begin{array}{c}\text { Profit per } \\
\text { hectare } \\
\text { growth rate }\end{array}$ & $\begin{array}{c}\text { Profit per } \\
\text { output unit } \\
\text { growth rate }\end{array}$ \\
\hline 1.0 & 0.0 & 0.000 & 2.6 & 1.6 & 0.616 \\
\hline 1.2 & 0.2 & 0.167 & 2.8 & 1.8 & 0.643 \\
\hline 1.4 & 0.4 & 0.286 & 3.0 & 2.0 & 0.667 \\
\hline 1.6 & 0.6 & 0.375 & 3.2 & 2.2 & 0.688 \\
\hline 1.8 & 0.8 & 0,445 & 3.4 & 2.4 & 0.706 \\
\hline 2.0 & 1.0 & 0.500 & 3.6 & 2,6 & 0.723 \\
\hline 2.2 & 1.2 & 0.546 & 3.8 & 2.8 & 0.737 \\
\hline 2.4 & 1.4 & 0.584 & 4.0 & 3.0 & 0.750 \\
\hline
\end{tabular}

Source: Calculated according to Formulas 3 and 4.

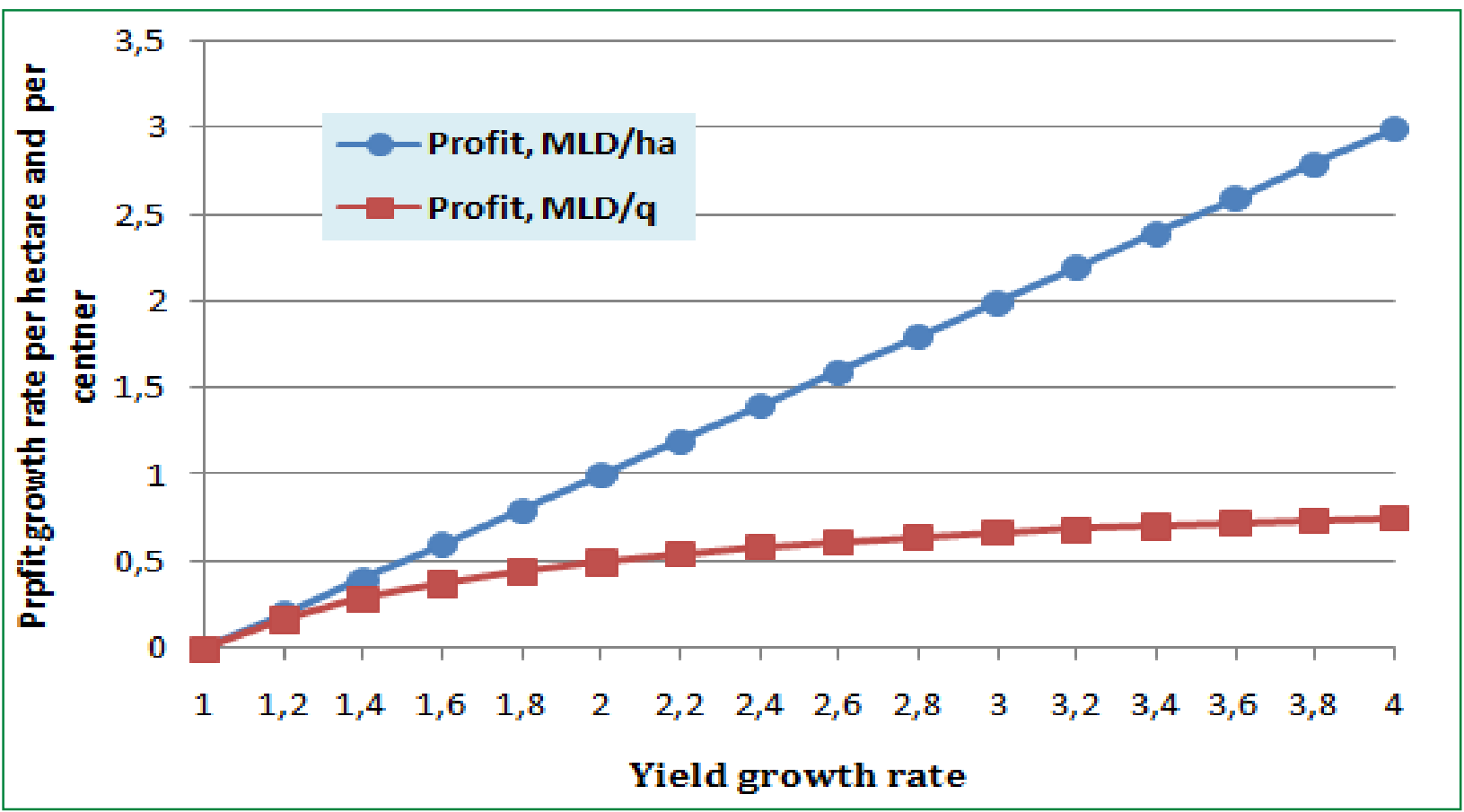

Figure 1. Influence of yield growth rate on profit per hectare growth rate and profit per $100 \mathrm{~kg}$ growth rate

Source: Produced from the data in Table 1.

Now we apply Formulas 5 and 6 to calculate the interdependence between the financial safety margin and the operating leverage on the yield growth rate (Table 2). The financial safety margin increases and the operating leverage decreases with growing yields. However, the graph in Figure 2 shows that the rates of the above changes are slowing down with growing yields. 
Interdependence between the financial safety margin and operating leverage and the yield growth rate

\begin{tabular}{|c|c|c|c|c|c|}
\hline $\begin{array}{c}\text { Yield growth } \\
\text { rate }\end{array}$ & $\begin{array}{c}\text { Financial } \\
\text { safety } \\
\text { margin }\end{array}$ & $\begin{array}{c}\text { Operating } \\
\text { leverage }\end{array}$ & $\begin{array}{c}\text { Yield growth } \\
\text { rate }\end{array}$ & $\begin{array}{c}\text { Financial } \\
\text { safety } \\
\text { margin }\end{array}$ & $\begin{array}{c}\text { Operating } \\
\text { leverage }\end{array}$ \\
\hline 1.0 & 0.000 & 0.00 & 2.6 & 0.616 & 1.62 \\
\hline 1.2 & 0.167 & 5.99 & 2.8 & 0.643 & 1.56 \\
\hline 1.4 & 0.286 & 3.50 & 3.0 & 0.667 & 1.50 \\
\hline 1.6 & 0.375 & 2.67 & 3.2 & 0.688 & 1.45 \\
\hline 1.8 & 0.445 & 2.25 & 3.4 & 0.706 & 1.42 \\
\hline 2.0 & 0.500 & 2.00 & 3.6 & 0.723 & 1.38 \\
\hline 2.2 & 0.546 & 1.83 & 3.8 & 0.737 & 1.36 \\
\hline 2.4 & 0.584 & 1.71 & 4.0 & 0.750 & 1.33 \\
\hline
\end{tabular}

Source: Calculated according to Formulas 5 and 6.

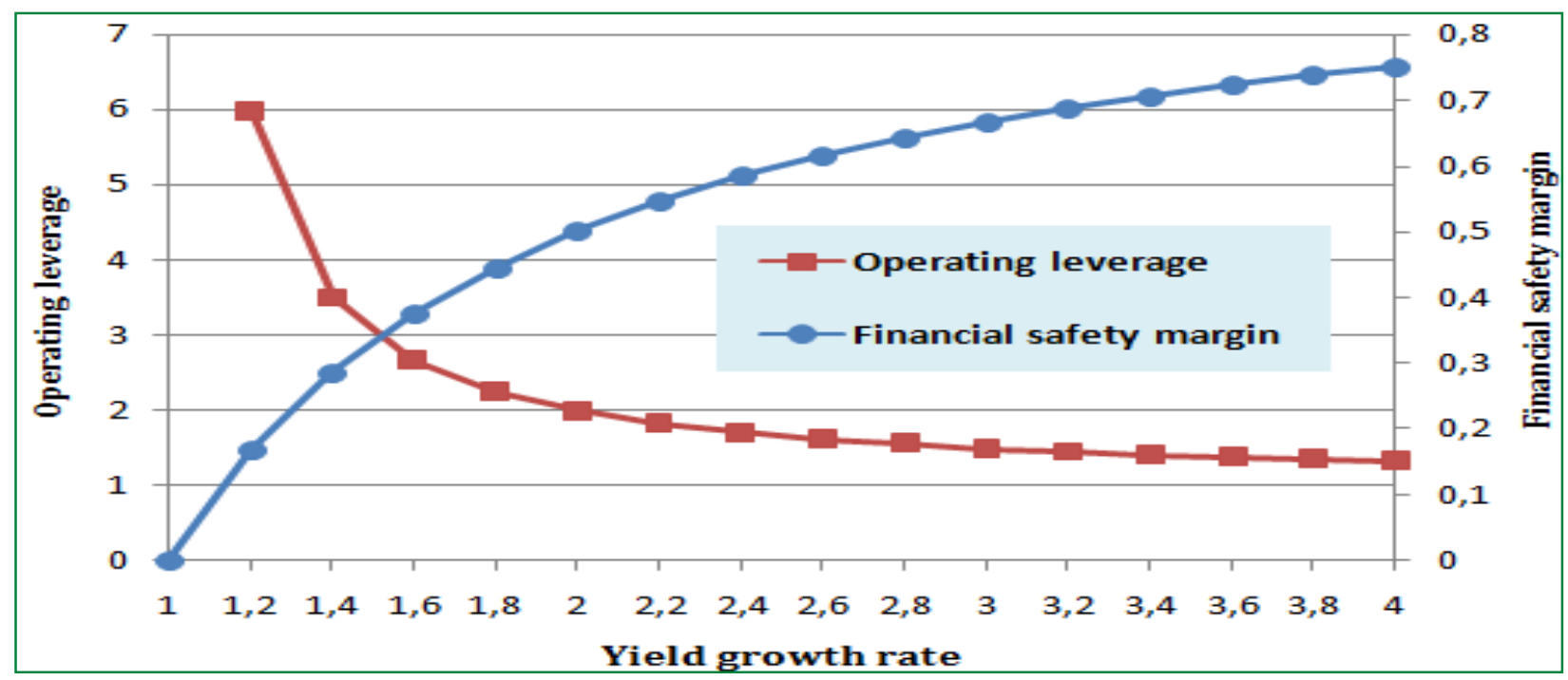

Figure 2. Interdependence between the financial safety margin and operating leverage and the yield growth rate

Source: Produced from the data in Table 2.

It is known that any agricultural enterprise usually cultivates more than one crop. The production and sale of some crops gives a high return on investments while some other crops have a low profit margin. Nevertheless, it is not always possible to discontinue production of these latter crops because of agro-technical crop rotation requirements or some other in-house and external reasons. In other words, sales of different products invariably have different profit margins. The profitability of a particular crop can fluctuate significantly in the Republic of Moldova, mainly because of the weather and climatic conditions prevailing during the crop cultivation and harvesting season, and range between loss and a profit margin of over $30 \%$. For example, the profit margin of grain sold in the Republic of Moldova fluctuated between $-3.5 \%$ in 2009 and $+39.9 \%$ in 2011; of sunflower seeds - between $16.6 \%$ in 2009 and $89.8 \%$ in 2010; of grapes - between $6.0 \%$ in 2009 and $37.0 \%$ in 2012 [13, 2018]. Therefore, a scientifically substantiated classification (gradation) of the sales profitability levels for diverse agricultural crops will be in demand because each level will indicate a particular efficiency range for cultivation of the crop concerned. It is important for an agricultural enterprise to know and thus to objectively budget the level of costs that will ensure a certain yield per hectare required to achieve sustainable and/or expanding reproduction. Thus, we have approached the problem of a substantiated profitability planning for each of the crops cultivated by the enterprise. 
Of course, the objective of any business entity is to ensure higher return on its production inputs. Nevertheless, for diverse reasons, the average 2001-2012 profit margins in agricultural enterprises in the southern zone of the Republic of Moldova for production and sales were: $43.8 \%$ for sunflower seeds, $46.0 \%$ for winter rape, $26.7 \%$ for grapes, $11.7 \%$ for legumes and grains other than corn, and 6.1\% for corn [13, 2018]. (Starting in 2013, Moldova has no longer published any data concerning the local production costs and so it is not possible to calculate the profit margins).

The profit margin is calculated for sales according to this formula:

$$
\mathrm{P}=\frac{\mathrm{N}-\mathrm{Z}}{\mathrm{Z}}=\frac{\Pi}{\mathrm{Z}}
$$

where:

$\mathrm{P}=$ profit from sales, in MDL;

$\mathrm{Z}=$ costs of production and sales, in MDL.

Thus, it has been demonstrated that the most important efficiency indicator of the product sales can be measured applying a relative value - the profit margin. In view of this measurement nature, it would be perfectly logical to ask this question: if profitability is relative in its nature, why not measure it applying some other relative indicators?

Marginal analysis is used for practical purposes, when planning the revenue from sales of products and the profit margin. Application of this method in financial management of local enterprises will enable more effective management of financial results. However, this is only possible where enterprise planning and cost accounting is organised according to the direct costing approach, i.e. where all costs are subdivided into fixed costs and variable costs.

Studies have demonstrated that the profit margin of sold products can be calculated after this formula [14, Parmacli D., Todorovici L., 2017]:

where:

$$
\mathrm{R}=\frac{\mathrm{p}-\mathrm{AVC}}{\mathrm{p}}+\mathrm{AVC}
$$

$\mathrm{p}=$ selling price, in MDL per $100 \mathrm{~kg}$ (metric centner);

$\mathrm{AVC}=$ variable costs per unit, in MDL per $100 \mathrm{~kg}$ (metric centner);

$\mathrm{f}=$ rate of return on fixed costs (i.e. profit divided by fixed costs)

If we assume that the selling price of products (p) divided by variable costs per unit (AVC) is $\mathrm{k}=\frac{\mathrm{p}}{\mathrm{AVC}}$ (return on variable costs per unit), then:

$$
\mathrm{R}=\frac{\mathrm{K}-1}{\frac{\mathrm{K}}{f}+1}
$$

The experience of agricultural enterprises in the southern zone of the Republic of Moldova has confirmed that profit per hectare of area under the crop should be not lower than fixed costs for sustainable reproduction (we will call this profitability level sustainable) and higher than fixed costs for expanding reproduction (a feasible profitability level). The optimal profitability level is the sales profitability level where profit is three-fold of fixed costs. In case of a high profitability level, profit is four-fold of fixed costs. The calculation formulas for the four profitability levels and the expected result are presented in Table 3.

Table 3

Sales profitability levels

\begin{tabular}{|l|c|c|c|}
\hline \multicolumn{1}{|c|}{$\begin{array}{c}\text { Profitability } \\
\text { level }\end{array}$} & $\begin{array}{c}\text { Profitability level } \\
\text { symbol }\end{array}$ & $\begin{array}{c}\text { Profit level } \\
\text { formula }\end{array}$ & $\begin{array}{c}\text { Expected result } \\
\text { (profit) }\end{array}$ \\
\hline Sustainable & $\mathrm{R}_{\text {sus }}$ & $\mathrm{R}_{\text {sus }}=\frac{\mathrm{K}-1}{\mathrm{~K}+1}$ & $\mathrm{P}=\mathrm{FC}$ \\
\hline Feasible & $\mathrm{R}_{\text {feas }}$ & $\mathrm{R}_{\text {feas }}=\frac{\mathrm{K}-1}{0,5 \kappa+1}$ & $\mathrm{P}=2 \mathrm{FC}$ \\
\hline Optimal & $\mathrm{R}_{\text {opt }}$ & $\mathrm{R}_{\text {opt }}=\frac{\mathrm{K}-1}{0,333 \mathrm{~K}+1}$ & $\mathrm{P}=3 \mathrm{FC}$ \\
\hline High & $\mathrm{R}_{\text {high }}$ & $\mathrm{R}_{\text {high }}=\frac{\mathrm{K}-1}{0,25 \mathrm{~K}+1}$ & $\mathrm{P}=4 \mathrm{FC}$ \\
\hline
\end{tabular}

Source: Table produced by the authors. 
Let us examine the calculations of these profitability levels for 2018 in Daalar Duzu SRL, an agricultural enterprise operating in Ceadir Lunga region, Republic of Moldova. The source data is presented in Table 4. (The standard rules for classification of costs into fixed costs and variable costs were developed by the Economic Research Institute [15, BAJURA, T., STRATAN, A. et al., 2018]). Table 5 shows the above-described profitability levels calculated for the said enterprise. It can be concluded from the table that the sustainable profitability level of wheat sales is in the range of 0 to 0.097 ; the feasible profitability level is in the range of 0.097 to 0.133 ; the optimal profitability level is in the range between 0.133 and 0.154 and the high profitability level is in the range between 0.154 and 0.166 and higher. A similar calculation can be made for other types of products.

It is important to point out that the profit margin growth rate slows down as each next (higher) profitability level (i.e. feasible, optimal, high) is reached. Thus, if the ratio between the feasible profitability and the sustainable profitability is 1.618 for wheat sales, the ratio between the optimal profitability and the feasible profitability is only 1.258 and the ratio between the high profitability and the optimal profitability is 1.150. A similar pattern can be identified for other crops.

2018 production and sales of the core crops in Daalar Duzu SRL

\begin{tabular}{|l|c|c|c|c|c|}
\hline \multicolumn{1}{|c|}{ Indicator } & Wheat & Peas & Corn & Sunflowers & $\begin{array}{c}\text { Soy } \\
\text { beans }\end{array}$ \\
\hline Selling price (p), MDL per 100 kg & 230.60 & 287.10 & 273.60 & 706.20 & 562.90 \\
\hline Fixed costs (FC), MDL per hectare & 1124.00 & 354.00 & 1235.00 & 958.00 & 319.00 \\
\hline $\begin{array}{l}\text { Variable costs per unit (AVC), } \\
\text { MDL per 100 kg }\end{array}$ & 189.66 & 176.13 & 187.96 & 326.04 & 192.57 \\
\hline Total costs (z), MDL per 100 kg & 219.00 & 202.0. & 216.60 & 373.50 & 220.80 \\
\hline Rate of return (K) & 1.216 & 1.630 & 1.456 & 2.166 & 2.924 \\
\hline
\end{tabular}

Source: Form 7-APK and Form 9-APK reports of Daalar Duzu SRL for 2018.

It should also be pointed out that each type of product has its own set of sustainable or other profitability levels. The reason is different fixed costs and variable costs per unit. For example, the ratio between the rates of return on fixed costs and on variable costs per unit is 2.40 in the production of soy beans and wheat - whereas the ratio between the profit margins for a sustainable, feasible, optimal and high profitability level is respectively: 5.05; 5.87; 6.33 and 6.69 . Thus, their profitability growth rates increase at each next (higher) sales efficiency level.

It should be noted that a full break-even on fixed costs is observed at the profit margin of $9.7 \%$ for sales of wheat; $18.6 \%$ for corn; $24.0 \%$ for peas; as high as $36.8 \%$ for sunflower seeds; and $49.0 \%$ for soy beans. Consequently, it is not possible to assess the efficiency of sales, applying the same profitability levels for grain, sunflower seeds, grapes and other products. Different profitability levels should be determined (graded) for each type of sold products in order to assess their efficiency or profitability. This can be done applying the methodology proposed in the foregoing in order to determine their sustainable, feasible, optimal and high profitability levels.

Table 5

Profit margin levels determined for products sold by Daalar Duzu SRL in 2018

\begin{tabular}{|l|c|c|c|c|c|}
\hline \multirow{2}{*}{ Profitability level } & \multicolumn{5}{c|}{ Calculated profit margins for } \\
\cline { 2 - 6 } & Wheat & Peas & Corn & Sunflower seeds & Soy beans \\
\hline Sustainable $\left(\mathrm{R}_{\text {sus }}\right)$ & 0.097 & 0.240 & 0,186 & 0.368 & 0.490 \\
\hline Feasible $\left(\mathrm{R}_{\text {feas }}\right)$ & 0.133 & 0,347 & 0.264 & 0.560 & 781 \\
\hline Optimal $\left(\mathrm{R}_{\text {opt }}\right)$ & 0.154 & 0.409 & 0.307 & 0.678 & 0.975 \\
\hline High $\left(\mathrm{R}_{\text {high }}\right)$ & 0.166 & 0.447 & 0.334 & 0.756 & 1.111 \\
\hline Actual $\left(\mathrm{R}_{\text {fact }}\right)$ & 0.053 & 0.421 & 0.265 & 0.891 & 1,549 \\
\hline Profitability assessment & sustainable & optimal & feasible & high & high \\
\hline
\end{tabular}

Source: Table produced by the authors. 
Analysing the actual profitability values of the product sales (Table 3), it can be noted that wheat production and sale has the lowest efficiency value assessed as sustainable (the actual profitability of 0.053 is below the sustainable profitability level of 0.097 ). The efficiency can be assessed as feasible in case of corn sales, as optimal for sales of peas, and as high for sales of sunflower seeds and soy beans.

How is the aggregate efficiency assessed for all crop sales in the farm? To answer this question, it is necessary to make calculations applying the methodology presented in Table 6. It is very easy and convenient in application. The rate of return on fixed costs for all crops is 2.97 and we can thus assess the aggregate efficiency of product sales as feasible.

The methodology for calculation of the aggregate efficiency of all crop

Table 6 sales in Daalar Duzu SRL in 2018

\begin{tabular}{|c|c|c|c|c|c|c|}
\hline \multirow[b]{2}{*}{ Crop } & \multirow[b]{2}{*}{$\begin{array}{c}\text { Area, } \\
\text { ha }\end{array}$} & \multicolumn{2}{|c|}{ Profit } & \multicolumn{2}{|c|}{ Fixed costs } & \multirow{2}{*}{$\begin{array}{l}\text { Rate of } \\
\text { return on } \\
\text { fixed costs }\end{array}$} \\
\hline & & $\begin{array}{c}\text { Total, } \\
\text { MDL thous. }\end{array}$ & $\begin{array}{l}\text { MDL per } \\
\text { hectare }\end{array}$ & $\begin{array}{l}\text { MDL per } \\
\text { hectare }\end{array}$ & $\begin{array}{c}\text { Total, } \\
\text { MDL thous. }\end{array}$ & \\
\hline Wheat & 629 & 280 & 445 & 1125 & 707.40 & 0.40 \\
\hline Peas & 194 & 226 & 1165 & 354 & 68.70 & 3.29 \\
\hline Corn & 535 & 1319 & 2465 & 1235 & 660.70 & 2.00 \\
\hline Sunflower seeds & 526 & 3537 & 6724 & 958 & 503.90 & 7.02 \\
\hline Soy beans & 137 & 530 & 3869 & 319 & 43.70 & 12.13 \\
\hline Total & 2021 & 5892 & 2915 & 982 & 1984.40 & 2.97 \\
\hline
\end{tabular}

Source: Form 7-APK and Form 9-APK reports of Daalar Duzu SRL for 2018.

By way of illustration, we present the actual data on the 2018 profitability of product sales in Daalar Duzu SRL and assessment thereof in Figure 3 and the extent to which the actual profitability of their sales exceeded (fell short of) the high profitability level in Figure 4.

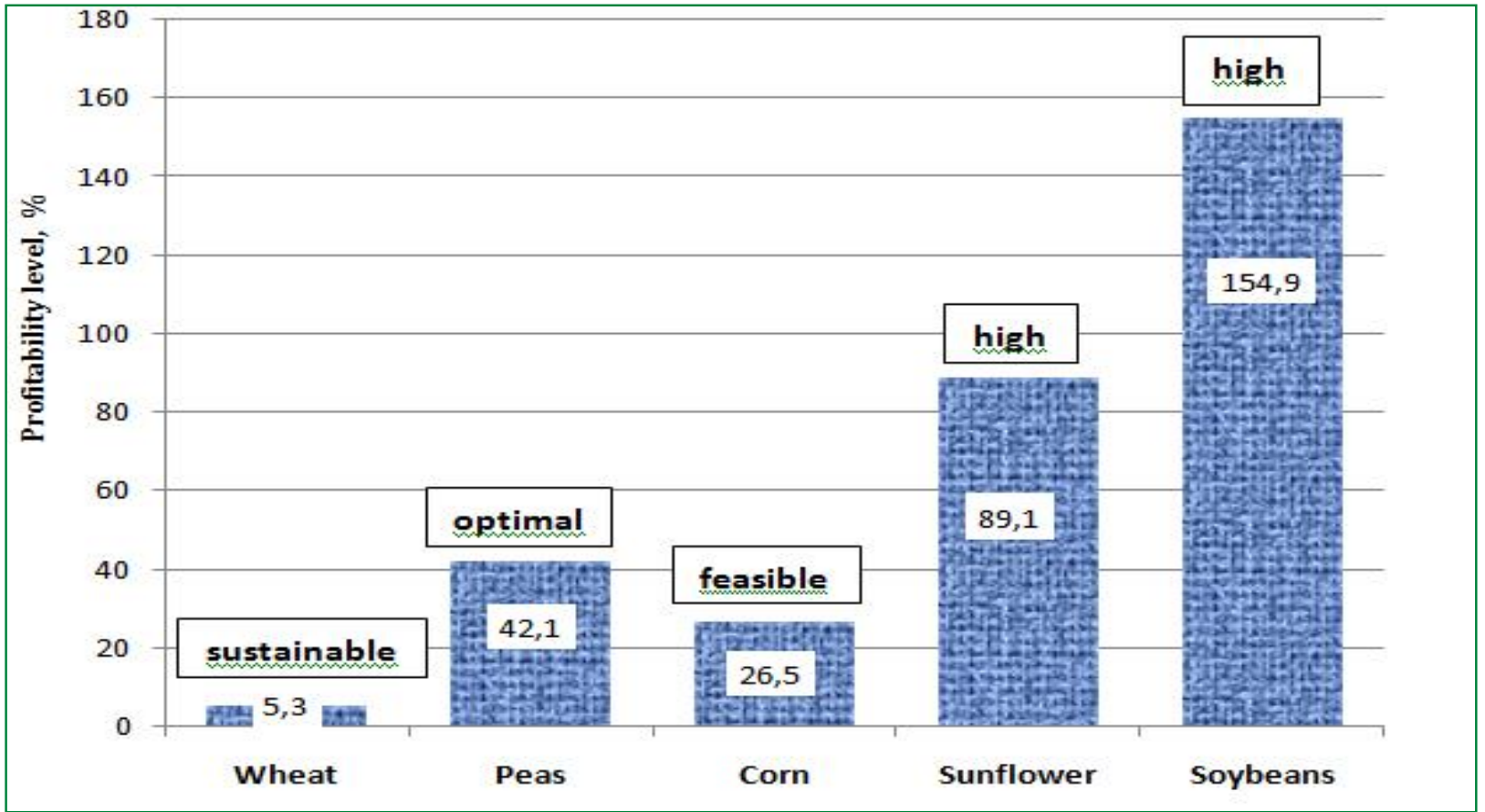

Figure 3. Actual profitability of 2018 product sales in Daalar Duzu SRL and assessment thereof

Source: Produced on the basis of Table 5. 


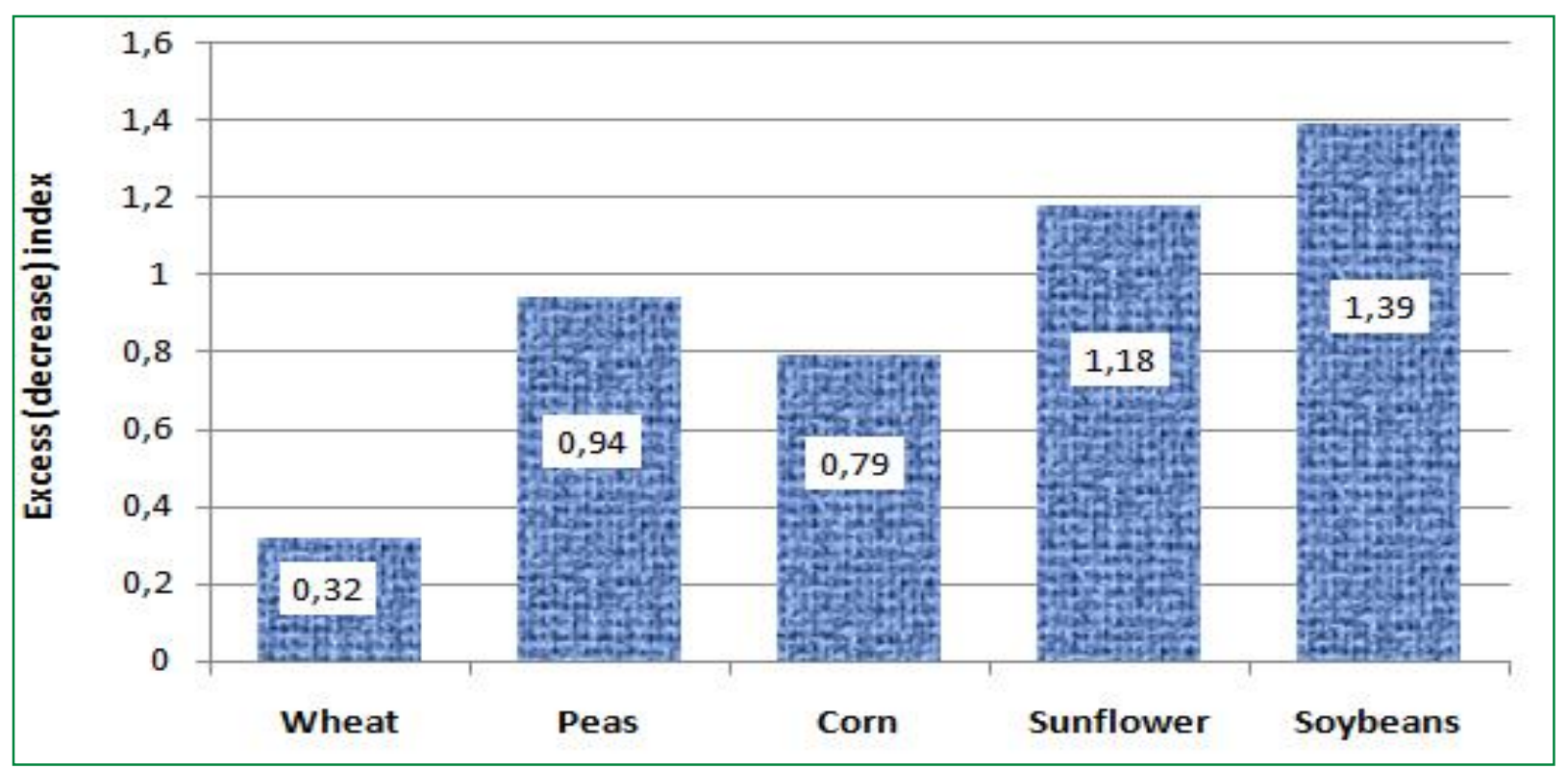

Figure 4. The extent to which the actual sales profitability exceeded (fell short of) the high profitability level in Daalar Duzu SRL in 2018

Source: Produced on the basis of Table 5.

\section{CONCLUSIONS}

The studies have shown that the moderate profitability of products ensures simple reproduction, in which the profit per hectare of sowing should not be lower than the value of fixed costs. Enhanced reproduction is provided by three types of profitability: within a rational one, the profit from product sales should exceed 2 times the value of fixed costs. The optimal level should be considered the level of profitability of the products sold, at which the profit is 3 times more than fixed costs. In case of high profitability, profit is 4 times higher than fixed costs. It is important that the functional relationship between the payback coefficient of fixed costs and the profitability ratio of products sold is represented by a simple formula, which greatly simplifies the task of researchers.

It should be noted as well that the foregoing will enable agricultural professionals operating with two rates of return (on fixed costs and on variable costs per unit) to determine the sustainable, feasible, optimal and high profitability levels for their sales of grain, sunflower seeds, grapes and other products and to substantiate the expected profit amount on the basis thereof.

\section{REFERENCES}

1. PABLIK, V.P. Problemi efektivnogo upravlinnâ sil'skogospodarskimi pidpriestvami. V: Ekonomika APK. 2015, № 11, ss. 85-88. н ISSN 2413-2322; ISSN 2221-1055. [Accesat 23.09.2019]. Disponibil: http://eapk.org.ua/sites/default/files/eapk/2015/11/13.pdf

2. ŠPIKULÂK, O.G., MATERINS'KA, O.A., MAZUR, G.F. Efektivnist' virobnictva zerna sil'skogospodars'kimi pidpriemstvami: teoretiko-metodologičnij aspekt. B: Ekonomika APK. 2014, № 12, ss. 42-49. ISSN 2413-2322; ISSN 2221-1055. [Accesat 23.09.2019]. Disponibil: http://eapk.org.ua/sites/default/files/eapk/14_12_42-49.pdf

3. RASSKAZOVA, A., ŽDANOVA, R. Osnovnye ponâtiâ èkonomičeskoj èffektivnosti upravleniâ ustojčivym zemlepol'zovaniem. V: Meždunarodnyj sel'skohozâjstvennyj žurnal. 2017, №1 2017, ss. 23-25. ISSN 2587-6740.

4. SIPTIC, S. Metody proektirovaniâ èffektivnyh i ustojčivyh variantov razmeŝeniâ sel'skohozâjstvennogo proizvodstva. V: Meždunarodnyj sel'skohozâjstvennyj žurnal. 2017, № 6, ss. 56-59. ISSN 2587-6740.

5. ROMANENKO, I.A., EVDOKIMOVA, N.E. Cenologičeskij podhod pri analize ustojčivosti razmeŝeniâ sel'skogo hozâjstva po regionam России. V: Meždunarodnyj sel'skohozâjstvennyj žurnal. 2017, № 6, ss. 60-63. ISSN 2587-6740. 
6. ALTUHOV, A.I. Soveršenstvovanie organizacionno-èkonomičeskogo mehanizma ustojčivogo razvitiâ agropromyšlennogo proizvodstva. V: Èkonomika sel'skoho-zâjstvennyh i pererabatyvaûŝih predpriâtij. 2016, №7, ss. 2-11. ISSN 0235-2494.

7. Hotărîrea Guvernului cu privire la aprobarea Strategiei de dezvoltare a sectorului agroalimentar în perioada anilor 2006-2015: nr. 1199 din 17.10.2006. In: Monitorul Oficial al Republicii Moldova. 2006, nr. 170-173, art. 1312. [Accesat 23.09.2019]. Disponibil: http://lex.justice.md/index.php?action=view\&view=doc\&lang=1\&id=318200

8. TIMOFTI, E., POPA, D. Eficienţa mecanismului economic în sectorul agrar: monografie. Chişinău: Complexul Editorial al IEFS, 2009. 343 p. ISBN 978-9975-9823-3-7.

9. PARMAKLI, D., TODORIČ, L. Problemy èkonomičeskoj ustojčivosti sel'skoho-zâjstvennyh predpriâtij Respubliki Moldova: monografiâ. Komrat: Tipogr. "Centrografic, 2013. 207 c. ISBN 9975-9751-8-6.

10. DUDOGLO, T.D. Uprevlenie zemel'nym potencialom regiona: voprosy teorii, metodiki, praktiki: monografiâ. Komrat: Tipogr. "Centrografic, 2017. 167 c. ISBN 978-9975-3132-3-0.

11. PARMAKLI, D.M., DUDOGLO, T.D. Urožajnost' i pribyl': metodologičeskie aspekty. In: Creșterea Economică în Condițiile Globalizării = Economic Growth in conditions of globalization: international conference on theoretical and applied economic practices, october 13-14 2016. 11-th edition. Chișinău, 2016, vol. 1, pp. 282-286. ISBN 978-9975-4185-9-9.

12. PARMAKLI, D.M. Metodika gradacii urovnej urožajnosti i zon èffektivnosti produkcii rastenievodstva. V: APK: èkonomika, upravlenie. 2016, №3, ss. 86-91. ISSN 0235-2443.

13. Anuarul Statistic al Republicii Moldova $=$ Statističeskij ežegodnik Respubliki Moldova = Statistical Yearbook of the Republic of Moldova 2018. Chișinău, 2018. 465 p. ISBN 978-997553-418-5.

14. PARMAKLI, D.M., TODORIČ, L.P. i dr. Produktivnost' zemli v sel'skom hozâjstve: èkonomičeskaâ teoriâ i hozâjstvennaâ praktika: monografiâ. Komratskij Gosudarstvennyj universitet, Naučno-issledovatel'skij centr «Progress». Komrat: Tipografia "Centrografic, 2017. 242 p. ISBN 978-9975-3132-7-8.

15. BAJURA, T., STRATAN, A. et al. Tarife de costuri în agricultură: Ghid practice. Chișinău: INCE, 2018. 164 p. ISBN 978-9975-3202-5-2.

\section{ARTICLE HISTORY}

Received 12 November 2019

Accepted 28 November 2019 